\title{
Stereochemistry of 2D Molecular Crystallization
}

\author{
Karl-Heinz Ernst ${ }^{* a b}$ \\ In memoriam Paul Hug
}

\begin{abstract}
Different stereochemical aspects of molecular recognition in two-dimensional crystallization on metal surfaces are discussed. Scanning tunneling microscopy, a powerful tool with submolecular resolution capabilities, provides detailed insight into the implications of molecular geometry for the two-dimensional crystal lattice. The examples presented here include a homo- to heterochiral phase transition, tiling with pentagonal molecules, chiral restructuring of a metal surface and diastereomeric recognition between enantiomers of different molecular species via polar forces as well as van der Waals interactions.
\end{abstract}

Keywords: Chirality $\cdot$ Conglomerate $\cdot$ Diastereomeric recognition $\cdot$ Fivefold symmetry $\cdot$ STM

\section{Introduction}

One of the goals of understanding crystallization is to establish the connection between the macroscopic properties of a crystalline material and the microscopic features of the constituent molecules. Because of the complexity of the problem, two-dimensional (2D) model studies are increasingly performed to obtain deeper insight into the process of molecular recognition during crystallization. The most important tool for studying 2D crystallization nowadays is scanning tunneling microscopy (STM). [1] In particular studying self-assembly of chiral molecules on single crystal surfaces is a promising approach towards a better understanding of optical resolution of enantiomers. ${ }^{[2]}$ It has revealed different chiral motifs of 2D molecular crystals. ${ }^{[3]}$ In particular lateral resolution, ${ }^{[4]}$ amplification of chirality ${ }^{[5]}$ and chiral switching have been addressed. ${ }^{6]}$

\footnotetext{
${ }^{\star}$ Correspondence: Prof. Dr. K.-H. Ernst ${ }^{\mathrm{ab}}$

Tel.: +41587654363

E-mail: karl-heinz.ernst@empa.ch

${ }^{\mathrm{a} E m p a}$ - Swiss Federal Laboratories for Materials

Science and Technology

Laboratory for Nanoscale Materials Science

Überlandstrasse 125

$\mathrm{CH}-8600$ Dübendorf

bepartment of Chemistry

University of Zurich

Winterthurerstrasse 190

$\mathrm{CH}-8057$ Zürich
}

In this paper different stereochemical phenomena connected with $2 \mathrm{D}$ crystallization are reviewed. First we present a molecular system in which a transition from a conglomerate to racemic crystals occurs; then we address recognition among different chiral species, analyze initial steps of chiral restructuring of a metal surface, and finally, discuss how fivefold-symmetric molecules form dense 2D crystals.

\section{Methods and Materials}

All systems were investigated in ultrahigh vacuum (UHV, $\mathrm{p} \approx 10^{-8} \mathrm{~Pa}$ ). The compounds to be studied were evaporated from effusion cells and deposited on the surfaces of metal crystals. Molecules were usually adsorbed with the metal surface held at room temperature, before the sample was cooled in order to perform STM studies at cryogenic temperatures. The polished single crystal surfaces $\mathrm{Cu}(111), \mathrm{Cu}(111)$ and $\mathrm{Cu}(110)$ ] were cleaned in vacuo by standard sputtering and annealing cycles as described in more detail elsewhere. ${ }^{[7]}$ Cleanliness of the surfaces as well as the coverage of the adsorbate were determined with STM; the quality of long-range order of the metal crystals was evaluated by low energy electron diffraction (LEED).

\section{Results and Discussion}

\subsection{From Conglomerate to Racemate}

It has been predicted that enantiomeric resolution in 2D systems should occur more easily than in three-dimensional (3D) crystals because certain symmetry ele- ments, like centers of inversion and glide planes parallel to the surface, are precluded on a surface and therefore enhanced chiral interactions are expected. ${ }^{[8]}$ However, so far no clear tendency towards $2 \mathrm{D}$ conglomerate crystallization has been observed. ${ }^{[2,4]}$ Sometimes the balance of intermolecular forces and molecule-substrate interactions may even lead to coexistence of homochiral and racemic phases. ${ }^{[9]}$ Phase transitions from a conglomerate with homochiral domains into a racemic phase have also been observed in chiral monolayers on crystal surfaces. ${ }^{[10]}$ An interesting example of such a transformation is found for $\mathrm{N}$, $\mathrm{N}^{\prime}$-dihexadecylquinacridone $\left(\mathrm{C}_{52} \mathrm{H}_{76} \mathrm{O}_{2} \mathrm{~N}_{2}\right.$; QA16C) deposited on a $\mathrm{Au}(111)$ surface (Fig. 1).[11] Quinacridone derivatives are used as organic semiconductor materials, and their interface structure at electrode surfaces is therefore of interest for understanding the performance of light-emitting devices. Besides the aromatic backbone, QA16C has two alkyl chains with sixteen carbon atoms each. The substituents make an isolated QA16C molecule a prochiral species. Depending on which enantiotopic side is facing the surface, an L or R adsorbate molecule will be formed.

QA16C on $\mathrm{Au}(111)$ forms three different phases. At low coverages homochiral domains are observed (Fig. 1d). Their unit cell is described by a $(2 \times 2)$ transformation matrix linking the adsorbate lattice vectors $\left(b_{1}, b_{2}\right)$ to the substrate lattice vectors $\left(a_{1}\right.$, $\left.\mathrm{a}_{2}\right): \mathrm{b}_{1}=\mathrm{m}_{11} \mathrm{a}_{1}+\mathrm{m}_{12} \mathrm{a}_{2}$ and $\mathrm{b}_{2}=\mathrm{m}_{21} \mathrm{a}_{1}+$ $\mathrm{m}_{22} \mathrm{a}_{2}$. For the low-coverage phase $\left(\mathrm{m}_{11}\right.$ $\left.\mathrm{m}_{12}, \mathrm{~m}_{21} \mathrm{~m}_{22}\right)$ is $(42,-38) .{ }^{[12]}$ The aromatic backbone is oriented parallel to the surface and the alkyl chains of adjacent molecules are interdigitated. With increasing coverage the homochiral rows of molecules are 


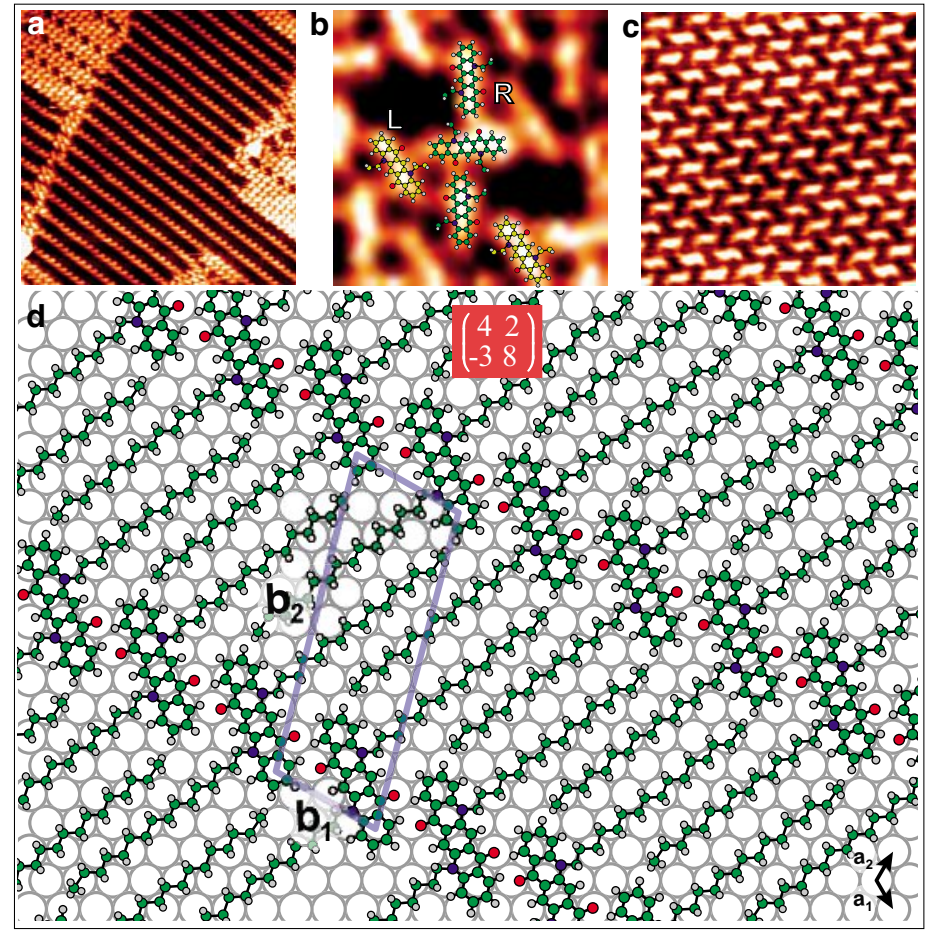

Fig. 1. STM images and model structure for QA16C on $\mathrm{Au}(111)$. (a) STM image of the homochiral low coverage phase $(50 \mathrm{~nm} \times 50 \mathrm{~nm}, \mathrm{U}$ $=1.2 \mathrm{~V}, \mathrm{I}=90 \mathrm{pA}$ ). (b) Intermediate 'ee'-structure with both enantiomers $(5 \mathrm{~nm} \times 5 \mathrm{~nm}, \mathrm{U}=$ $1.1 \mathrm{~V}, \mathrm{I}=80 \mathrm{pA})$. (c) Racemate phase at saturation coverage $(16 \mathrm{~nm} \times 16 \mathrm{~nm}, \mathrm{U}$ $=1.1 \mathrm{~V}, \mathrm{I}=80 \mathrm{pA}$ ). (d) Structure model of the homochiral low coverage phase. (Reproduced with permission of the ACS) broken up by their enantiomers (Fig. 1b), so that alternating rows of opposite handedness are formed. At the same time the alkyl chains are lifted off the surface, and cannot be resolved by STM anymore. This intermediate phase shows locally enantiomeric excess $(e e)$. The phase at saturation coverage shows densely packed molecules with two enantiomers per unit cell. The plane group is $p 2 g g$ with two mirror-glide planes $g$ perpendicular to the surface. Moreover, density functional theory (DFT) also suggests that the high coverage phase is indeed racemic.

The transition from the low coverage enantiomorphous phase to the closepacked racemate structure is driven by the gain of total adsorption energy. Several kinds of interaction energies contribute to the heat of adsorption: i) the interaction of the aromatic backbone with the surface, ii) the interaction of the alkyl chains with the surface, iii) the van der Waals interaction between the alkyl chains, and iv) hydrogen bonding between the oxygen and hydrogen atoms of the aromatic backbone. Because the alkyl chains point away from the surface at the end of the transition, it is likely that the gain in adsorption energy is due to the increased aromatic core-substrate interactions. It cannot be excluded, however, that $\pi$-H interactions of the chains lying on top of the aromatic part also contribute to some extent. The removal of the alkyl chains from the metal surface imposes an activation barrier to this process.

$\mathrm{On} \mathrm{Cu}(110)$, QA16C forms an almost identical low-coverage lamellar phase, but does not undergo any phase transition to a higher coverage phase. ${ }^{[13]}$ It appears that the alkyl chain-substrate interaction is responsible for the difference in behavior as it is too strong in the case of $\mathrm{Cu}(110)$ to allow formation of a denser racemic structure. The adsorption energy for a single hexadecane molecule on Au(111) serves as a rough estimate for the activation barrier associated with the removal of the hexadecyl chains from the metal surface. It was calculated via density functional theory (DFT) to be $67 \mathrm{~kJ} / \mathrm{mol}$, but this could be an underestimate, because lateral van der Waals interactions between the interdigitated chains have not been considered. For comparison, adsorption energies deduced from thermal desorption of alkanes on various surfaces or physisorption of alkane thiolate on gold range from 67 to $150 \mathrm{~kJ} /$ mol for alkanes with 10 to 16 carbon atoms. ${ }^{[11]}$

\subsection{Diastereomeric Recognition}

A common technique for separation of enantiomers and still the most important way to enantiopure compounds is diastereomeric salt crystallization. ${ }^{[14]}$ In 2D systems diastereomeric selectivity has been observed for acid-base pairs at the solid-liquid interface. ${ }^{[15]} 2 \mathrm{D}$ crystallization experiments with helicenes and ortho-annulated carbohelicenes which have outstanding material and chiroptical properties, ${ }^{[16]}$ showed interesting behavior. ${ }^{[17,18]}$ On $\mathrm{Cu}(111)$ heptahelicene $([7] \mathrm{H}$, $\mathrm{C}_{30} \mathrm{H}_{18}$ (Fig. 2a)) forms racemic 2D crystals. ${ }^{[19]}$ On the same surface lateral separation into a 2D conglomerate was observed for polar 6,13-dicyano-[7]H.[18a] These results support early predictions, that heterochiral recognition is favored for van der
Waals interactions and homochiral recognition for polar interactions. ${ }^{[20]}$ Moreover, when repulsion becomes significant in close-packed adlayers, chiral discrimination should be more pronounced due to better recognition of molecular shape. ${ }^{[21]}$ Until recently no spontaneous 2D resolution for non-functionalized helicenes has been reported. ${ }^{[22]}$ However, dibenzopentahelicene db-[5] $\left(\mathrm{C}_{30} \mathrm{H}_{18}\right)$, an isomer of [7] $\mathrm{H}$ does show 2D conglomerate crystallization on $\mathrm{Au}(111)$ (Fig. 2). Mirror domains are observed, i.e. domains that cannot be superimposed by translation or rotation in the plane (Fig. 2b, colored in red and green). High-magnification STM images of single domains allow the determination of the sense of helicity of single molecules and reveal that the domains are homochiral. The unit cell contains four molecules and has $(62,013)$ periodicity with respect to the gold(111) substrate lattice. This implies that $78 \mathrm{Au}$ atoms are covered by four molecules. The lengths of the unit cell vectors are $1.52 \mathrm{~nm}$ and $3.74 \mathrm{~nm}$.

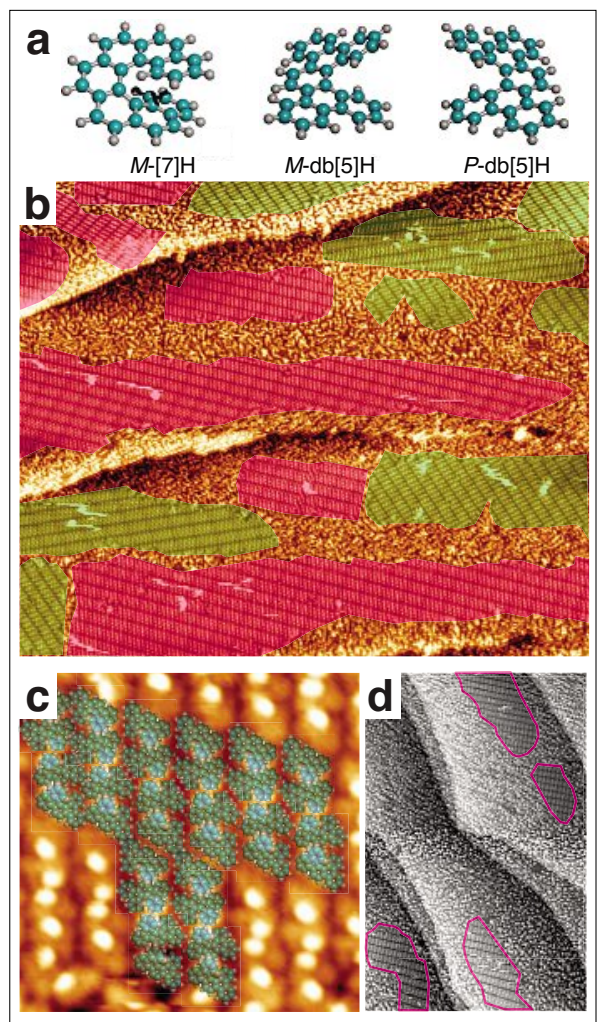

Fig. 2. (a) $\mathrm{M}-[7] \mathrm{H}, \mathrm{M}$ - and P-dibenzopentahelicene $(\mathrm{db}[5] \mathrm{H})$. (b) STM image of homochiral $\mathrm{P}$ - and $\mathrm{M}-\mathrm{db}[5] \mathrm{H}$ domains on $\mathrm{Au}(111)$ colored in green and red respectively $(200 \mathrm{~nm} \times 170$ $\mathrm{nm}, \mathrm{U}=-2.725 \mathrm{~V}, \mathrm{I}=25 \mathrm{pA}$ ). (c) STM image of a homochiral domain of M-db[5]H $(10 \mathrm{~nm} \times 10$ $\mathrm{nm}, \mathrm{U}=2.051 \mathrm{~V}, \mathrm{I}=28 \mathrm{pA}$ ). A semitransparent structural model is superimposed onto the image. (d) STM image of the racemic $\mathrm{dB}[5] \mathrm{H}$ layer with $20 \% \mathrm{M}-[7] \mathrm{H}$ mixed into it $(130 \mathrm{~nm}$ $\times 200 \mathrm{~nm} \mathrm{U}=-2.725 \mathrm{~V}, \mathrm{I}=66 \mathrm{pA}$ ). Apart from large disordered areas, only the $\mathrm{M}-\mathrm{dB}[5] \mathrm{H}$ enantiomorph (framed in red) is observed. (Reproduced with permission of the ACS) 
Coadsorption of racemic $\mathrm{db}$-[5] with one enantiomer of [7] H leads to successive suppression of one enantiomorph and substantial increase of disordered areas. Fig. $2 \mathrm{~d}$ shows a layer containing $20 \% \mathrm{M}-[7] \mathrm{H}$ (judged by covered area), which corresponds to a diastereomeric excess of $26 \%$. At this excess the only ordered domains are those formed by M-db[5]. This means that $\mathrm{M}-[7] \mathrm{H}$ preferably interacts with $\mathrm{P}-\mathrm{db}[5] \mathrm{H}$. Hence the M-P dimer is more stable than its $\mathrm{M}-\mathrm{M}$ diastereomer, and $\mathrm{M}-\mathrm{db}[5] \mathrm{H}$ is left alone to form its enantiomorph. However, most of the molecules go into a disordered solution due to this $\mathrm{M}-[7] \mathrm{H}-$ doping. A tentative model for a $\mathrm{M}-[7] \mathrm{H} / \mathrm{P}-\mathrm{db}[5] \mathrm{H}$ van der Waals complex is shown in Fig. 3a.

Already Pasteur reported a quasiracemate when co-crystallizing tartaric acid (TA) and malic acid (MA). ${ }^{[23,24]}$ On $\mathrm{Cu}(110)$ racemic TA forms a $2 \mathrm{D}$ conglomerate of homochiral $(12,-8$ 2) and (1 -2, 8 2) domains. ${ }^{[10 \mathrm{~b}]}$ When the TA racemate is mixed with $(R)$-MA, $(S, S)$-TA prefers a mixture with $(R)$-MA which leaves only tallization is perturbed. DFT calculations show that in a mixture of racemic TA and $(R)$-MA hydrogen bonding between $(R)$ MA and $(S, S)$-TA is preferred over other diastereomeric combinations (Fig. 3b). ${ }^{[25]}$

\subsection{Chiral Reconstruction of a Metal Surface}

Adsorption of chiral molecules may induce a chiral restructuring of the underlying crystal surface. This has been reported for calcite in liquid environment, for other biominerals and for amino acids on copper.[26] Electro-oxidation of copper in the presence of TA also created chiral surfaces. ${ }^{[27]}$ Like TA ${ }^{[28]}$ MA forms a rich family of structures on $\mathrm{Cu}(110) .{ }^{[29]}$ For the racemate the LEED diffraction pattern reveals a superposition of enantiomorphous domains with $(11,95)$ and $(1-1,95)$ periodicity (Fig. 4a). This phase forms at a coverage of 0.19 molecules per $\mathrm{Cu}$ surface atom after annealing for $30 \mathrm{~min}$ at $348 \mathrm{~K}$. The STM image shows that the periodicity is actually based on copper adatom breaking of the mirror-symmetry must thus be based on a chiral alignment of the enantiomers in the pair, i.e. the dimer motif containing both enantiomers breaks mirror symmetry.

Prolonged annealing at $383 \mathrm{~K}$ leads only to diffuse LEED patterns, but STM reveals small islands of new structures. Shown in Fig. $4 d$ is the one that has pairs of $\mathrm{Cu}$ adatom rows that are decorated on both sides (marked in blue in Fig. 4d). The structure can be considered as a combination of a decorated double row with a $(1 \pm 1$, $\mp 52)$ unit-cell and a not decorated $(1 \pm 1$, $\mp 41)$ cell. Models for the two chiral motifs, i.e. the decorated $(11,-52)$ double row and the not decorated $(11,-41)$ double row, are shown in Fig. 4f. This structure constitutes a chiral metal surface. Apparently the annealing procedure has caused the molecules to decompose or diffuse away, without repositioning of the copper atoms into their $(1 \times 1)$ structure. Fig. 4 e shows the $(11,-41)$ domain of this phase.

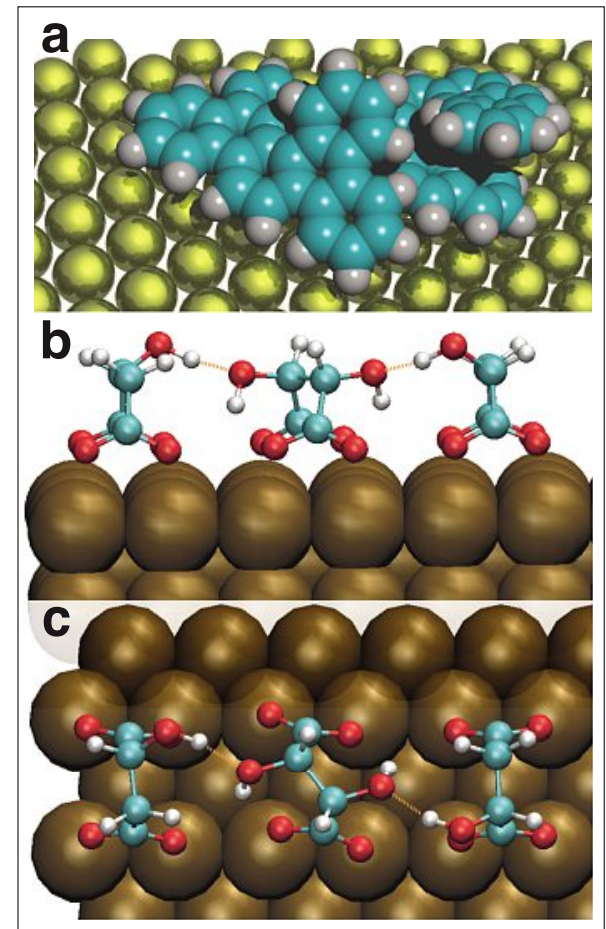

Fig. 3. (a) Model of a van der Waals quasiracemic pair formed by $\mathrm{P}-\mathrm{db}[5] \mathrm{H}$ and $\mathrm{M}-[7]$ $\mathrm{H}$ on $\mathrm{Au}(111)$. (b, c) Side and top view of quasi-racemic interaction via hydrogen bonds between $(S, S)$-tartaric acid and two $(R)$-malic acid molecules on $\mathrm{Cu}(110)$. (Reproduced with permission of the RCS)

$(R, R)$-TA domains to be observed.[25] $\mathrm{A}$ quite similar situation is observed for TA on $\mathrm{Cu}(110)$ with an $e e \geq 20 \%$. ${ }^{[5 \mathrm{~h}]}$ The chiral conflict can thus be introduced either by the appropriate enantiomer of a different, but closely related species, or by enantiomeric excess; in both cases the homochiral crys-
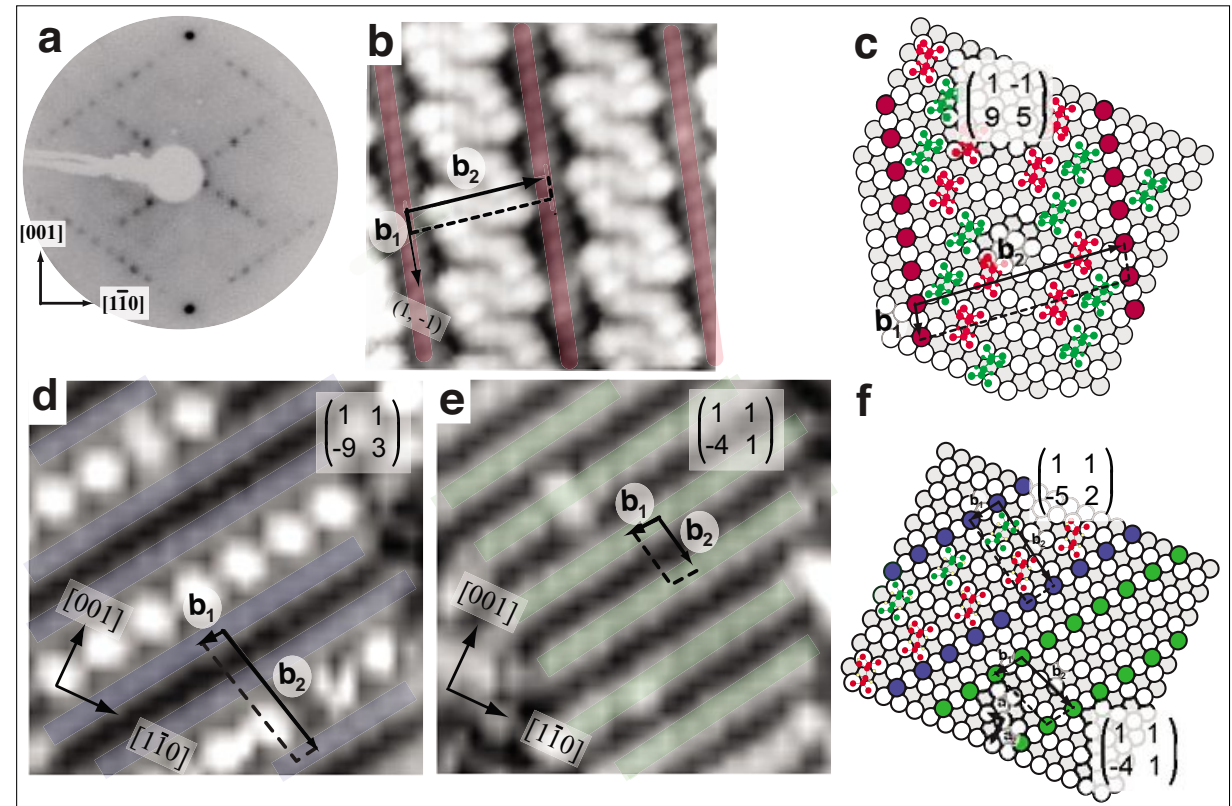

Fig. 4. Copper adatoms are arranged such that the mirror symmetry of this fcc(110) surface is broken. (a) LEED pattern of $(1 \pm 1,95)$ structures $\left(E_{p}=23 \mathrm{eV}\right)$. (b) STM image of the $(1-1,95)$ enantiomorph $(7 \mathrm{~nm} \times 7 \mathrm{~nm}, \mathrm{U}=-2.0 \mathrm{~V}, \mathrm{I}=50 \mathrm{pA})$. Cu adatom rows are decorated with molecules. (c) Model structure for the (1-1, 95) phase. Copper adatoms (red) are sitting in the centres of rectangles of Cu surface atoms (white) and arranged such that the mirror symmetry of the fcc(110) surface is broken. (d) STM image of a $(11,-93)$ structure with Cu adatom rows (blue) decorated only on one side $(6 \mathrm{~nm} \times 6 \mathrm{~nm}, \mathrm{U}=-1.93 \mathrm{~V}, \mathrm{I}=50 \mathrm{pA})$. (e) STM image of a chiral domain built-up only by copper atoms $(6 \mathrm{~nm} \times 6 \mathrm{~nm}, \mathrm{U}=-1.93 \mathrm{~V}, \mathrm{I}=50 \mathrm{pA})$. (f) Model of the chiral metal structure with the decorated (blue) and the non-decorated double rows (green). (Reproduced with permission of Wiley)

rows, running along the $<1,1>$ vector of the surface (Fig. $4 b, c)$. The atoms of these rows appear to be stabilized by the interaction with the MA molecules. Because this phase has not been observed for the pure enantiomers, it was concluded that heterochiral pairs are the decorating motifs. The

\subsection{Close-Packing of Pentagonal Molecules}

Fivefold symmetry is quite common in nature (brittle stars, flowers, etc.), but is not compatible with translational periodicity of a crystal lattice. ${ }^{[30,31]}$ This raises the question how fivefold-symmetric 
molecules crystallize in the plane. Perfect tilings would require the fivefold-symmetric shapes to be combined with other shapes, ${ }^{[32]}$ as demonstrated by Dürer, Kepler and Penrose. ${ }^{[33]}$

Self-assembly of fivefold-symmetric shape-persistent macro-cycles has been previously studied at the solid-liquid interface, ${ }^{[34]}$ and pentagonal features were discussed for rubrene and para-terphenyldicyanocerium on noble metal surfaces. ${ }^{[35,36]}$ However, systematic studies of closepacking strategies of pentagonal molecules in the plane have only been addressed with penta-substituted derivatives of corannulene so far. [37]

Corannulene (COR) has $\mathrm{C}_{5 \mathrm{v}}$ symmetry and offers, together with its $\mathrm{C}_{5}$-symmetric penta-substituted derivatives, the opportunity to study symmetry mismatching on surfaces. ${ }^{[38]}$ Previously, corannulene derivatives have been studied to understand not only their packing strategies in the plane, but also their bi-component packing, [39] 2D phase transitions, ${ }^{[40]}$ surface-induced ball-in-bowl and bowl-in-bowl complexation, ${ }^{[41]}$ and their substantial interface dipole moments without charge transfer. ${ }^{[42]}$ On $\mathrm{Cu}(111) \mathrm{COR}$ adsorbs in a tilted geometry with one six-membered ring oriented parallel to the surface. ${ }^{[40]}$ Substituents at the rim, however, force the bowl to orient its $\mathrm{C}_{5}$ axis normal to the surface, because of overcrowding between the substituents and the surface in a tilted geometry. ${ }^{[37]}$ Interestingly, 2D packing motifs established by penta-substituted corannulene derivatives are quite similar to tiling with rigid pentagons.[43] 1,3,5,7,9-penta-methylcorannulene $\left(\mathrm{Me}_{5} \mathrm{COR}\right)$, for example, has a shape that comes very close to that of a regular pentagon (Fig. 5a). The densest $2 \mathrm{D}$ packing motif of rigid regular pentagons is a $p 2 m g$ phase, covering $92.1 \%$ of the entire area (Fig. 5b). Self-assembled on $\mathrm{Cu}(111), \mathrm{Me}_{5} \mathrm{COR}$ forms exactly such a phase, as revealed by STM (Fig. 5c). Remarkably, these molecules follow the same packing strategies as corresponding rigid geometric objects, at least at low temperatures. Lateral van der Waals interactions between the methyl groups contribute substantially to the stabilization of such a packing. ${ }^{[37 c]}$ Upon excitation of soft bowlvibrations with increasing temperature the entropy of the lattice increases substantially, leading to phase transitions into lower density phases. ${ }^{[44]}$

\section{Conclusions and Outlook}

Today's STM technology allows the study of 2D crystals and crystallization of molecules on solid surfaces. Submolecular resolution, in combination with a clever choice of molecules, provides valuable in-
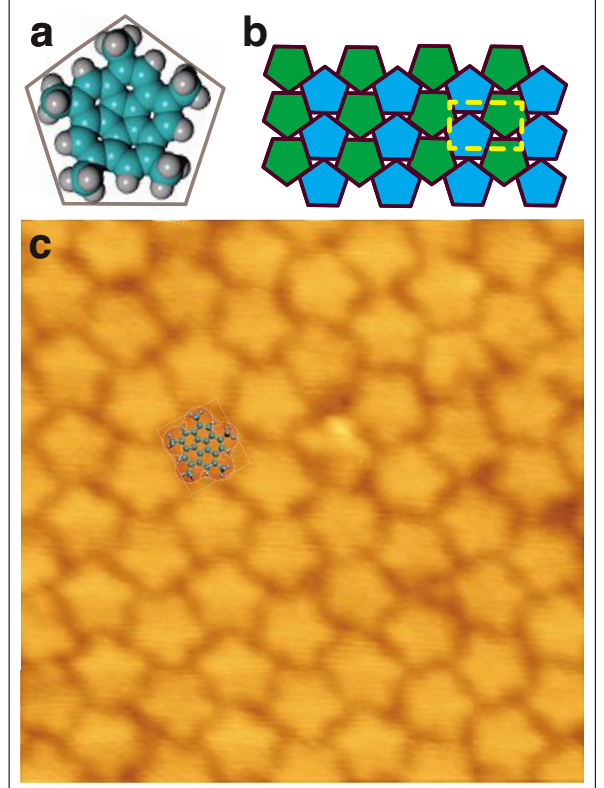

Fig. 5. Close-packing of pentagonal molecules. (a) $\mathrm{Me}_{5} \mathrm{COR}$ is well approximated by a pentagon. (b) The densest packing of pentagons in a plane has $p 2 m g$ plane group symmetry. (c) The densest packing observed for $\mathrm{Me}_{5} \mathrm{COR}$ with STM has also $\mathrm{p} 2 \mathrm{mg}$ plane group symmetry $(8.6 \mathrm{~nm} \times 8.6 \mathrm{~nm}, \mathrm{U}=-1.45 \mathrm{~V}, \mathrm{I}=0.428 \mu \mathrm{A})$. (Reproduced with permission of the RCS)

sight into the stereochemistry of molecular recognition. Noble metal substrates offer a high molecular mobility that mimics the 'liquid' phase and subsequent sample cooling induces nucleation and 2D crystal growth. With the ever-improving highresolution scanning probe microscopies (SPM), it will soon be possible to measure intermolecular forces directly. In combination with single-molecule manipulation, as provided now by SPM, many riddles surrounding crystallization and crystal structure, such as phase transitions, polymorphism and optical resolution, will be better understood. In contrast to the averaging diffraction techniques, local proximal probes will certainly cause a paradigm shift, because they allow direct observation of defects, impurities, dislocations, etc. and thus will help to gauge the importance of structural imperfections for the outcome of the macroscopic result.

\section{Acknowledgement}

Support by the Schweizerischer Nationalfonds, the University of Zurich (UFSP LightChEC) and the Swiss Sino Science and Technology Corporation (SSSTC) is gratefully acknowledged.

Received: November 18, 2013

[1] S. De Feyter, F. C. De Schryver, Chem. Soc. Rev. 2003, 32, 139; b) W.-D. Schneider, Chimia 2012, 66, 16; c) K.-H. Ernst, Chimia 2012, 66, 6.
[2] a) K.-H. Ernst, Phys. Status Solidi B 2012, 249 , 2057; b) R. Raval, Chem. Soc. Rev. 2009, 38, 707; c) N. Katsonis, E. Lacaze, B. L. Feringa, J. Mat. Chem. 2008, 18, 2065; d) J. A. A. W. Elemans, I. De Cat, H. Xu, S. De Feyter, Chem. Soc. Rev. 2009, 38, 722; e) K.-H. Ernst, Surf. Science 2013, 613, 1.

[3] a) M. Böhringer, K. Morgenstern, W.-D. Schneider, R. Berndt, F. Mauri, A. D. Vita, R. Car, Phys. Rev. Lett. 1999, 83, 324; b) M. C. Blüm, E. Cavar, M. Pivetta, F. Patthey, W.D. Schneider, Angew. Chem. Int. Ed. 2005, 44, 5334; c) A. Kühnle, T. Linderoth, F. Besenbacher, J. Am. Chem. Soc. 2003, 125, 14680; d) K. Sun, T.-N. Shao, J.-L. Xie, M. Lan, H.-K. Yuan, Z.-H. Xiong, J.-Z. Wang, Y. Liu, Q.-K. Xue, Small 2012, 8, 2078.

[4] a) S. M. Barlow, R. Raval, Surf. Sci. Rep. 2003, 50, 201; b) K.-H. Ernst, Top. Curr. Chem. 2006, $265,209$.

[5] a) K.-H. Ernst, Curr. Opin. Coll. Interf. Sci. 2008, 13, 54; b) I. Destoop, H. Xu, C. OliverasGonzález, E. Ghijsens, D. B. Amabilino, S. De Feyter, Chem. Comm. 2013, 49, 7477; c) H. Xu, E. Ghijsens, S. J. George, M. Wolffs, Z. Tomović, A. P. H. J. Schenning, S. De Feyter, ChemPhysChem 2013, 14, 1583; d) K.-H. Ernst, Orig. Life Evol. Biosphere 2010, 40, 41; e) F. Masini, N. Kalashnyk, M. M. Knudsen, J. R. Cramer, E. Lægsgaard, F. Besenbacher, K. V. Gothelf, T. R. Linderoth, J. Am. Chem. Soc. 2011, 133, 13910; f) M. Parschau, S. Romer, K.H. Ernst, J. Am. Chem. Soc. 2004, 126, 15398; g) M. Parschau, T. Kampen, K.-H. Ernst, Chem. Phys. Lett. 2005, 407, 433; h) S. Haq, N. Liu, V. Humblot, A. P. J. Jansen, R. Raval, Nature Chem. 2009, 1, 409.

[6] a) V. Simic-Milosevic, J. Meyer, K. Morgenstern, Angew. Chem. Int. Ed. 2009, 48, 4061; b) M. Parschau, D. Passerone, K.-H. Rieder, H. J. Hug, K.-H. Ernst, Angew. Chem. Int. Ed. 2009, 48 ,4065; c) S. Weigelt, C. Busse, L. Petersen, E. Rauls, B. Hammer, K. V. Gothelf, F. Besenbacher, T. R. Linderoth, Nature Mat. 2006, 5, 112; d) C. Busse, S. Weigelt, L. Petersen, E. Lægsgaard, F. Besenbacher, T. R. Linderoth, A. H. Thomsen, M. Nielsen, K. V. Gothelf, J. Phys. Chem. B 2007, 111, 5850.

[7] a) B. Behzadi, D. Ferri, A. Baiker, K.-H. Ernst, Appl. Surf. Sci. 2007, 253, 3480; b) K.-H. Ernst, D. Schlatterbeck, K. Christmann, Phys. Chem. Chem. Phys. 1999, 1, 4105; c) K.-H. Ernst, Y. Kuster, R. Fasel, M. Müller, U. Ellerbeck, Chirality 2001, 13, 675.

[8] M. Lahav, L. Leiserowitz, Angew. Chem. Int. Ed. 1999, 38, 2533.

[9] a) W. Mamdouh, M. D. Dong, R. Kelly, L. N. Kantorovich, F. Besenbacher, J. Phys. Chem. B 2007, 111, 12048; b) R. Cortes, A. Mascaraque, P. Schmidt-Weber, H. Dil, T. U. Kampen, K. Horn, Nano Letters 2008, 8, 4162; c) T. Balandina, M. W van der Meijden, O. Ivasenko, D. Cornil, J. Cornil, R. Lazzaroni, R. M. Kellog, S. De Feyter, Chem. Commun. 2013, 49, 2207.

[10] a) B. Behzadi, S. Romer, R. Fasel, K.-H. Ernst, J. Am. Chem. Soc. 2004, 126, 9176; b) S. Romer, B. Behzadi, R. Fasel, K.-H. Ernst, Chem. Eur. J. 2005, 11, 4149; c) F. Vidal, E. Delvigne, S. Stepanow, N. Lin, J. V. Barth, K. Kern, J. Am. Chem. Soc. 2005, 127, 10101; d) S. Stepanow, N. Lin, F. Vidal, A. Landa, M. Ruben, J. V. Barth, K. Kern, Nano Letters 2005 , 5, 901; e) M. Böhringer, W. D. Schneider, R. Berndt, Angew. Chem. Int. Ed. 2000, 39, 792.

[11] B. Yang, Y. Wang, H. Cun, S. Du, M. Xu, Y. Wang, K.-H. Ernst, H.-J. Gao, J. Am. Chem. Soc. 2010, 132, 10440.

[12] a) R. L. Park, H. H. Madden, Surf. Science 1968, 11, 188; b) L. Merz, K.-H. Ernst, Surf. Sci. 2010, 604, 1049.

[13] H. Cun, Y. Wang, B. Yang, S. Du, Y. Wang, K. H. Ernst, H.-J. Gao, Langmuir 2010, 26, 3402. 
[14] R. A. Sheldon, 'Chiral Technologies: Industrial synthesis of optically active compounds', M. Dekker, New York, 1993.

[15] H. Xu, W. J. Saletra, P. Iavicoli, B. Van Averbeke, E. Ghijsens, K. S. Mali, A. P. H. J. Schenning, D. Beljonne, R. Lazzaroni, D. B. Amabilino, S. De Feyter, Angew. Chem. Int. Ed. 2012, 51, 11981

[16] Y. Shen, C.-F. Chen, Chem. Rev. 2012, 112, 1463

[17] a) K.-H. Ernst, M. Böhringer, C. F. McFadden, P. Hug, U. Müller, U. Ellerbeck, Nanotechnology 1999, 10, 355; b) K.-H. Ernst, Y. Kuster, R. Fasel, C. F. McFadden, U. Ellerbeck, Surf. Sci. 2003, 530, 195; c) R. Fasel, A. Cossy, K.-H. Ernst, F. Baumberger, T. Greber, J. Osterwalder, J. Chem. Phys. 2001, 115, 1020; d) K.-H. Ernst, M. Neuber, M. Grunze, U. Ellerbeck, J. Am. Chem. Soc. 2001, 123, 493; e) R. Fasel, M Parschau, K.-H. Ernst, Angew. Chem. Int. Ed. 2003, 42, 5178; f) R. Fasel, M. Parschau, K.-H. Ernst, Nature 2006, 439, 449; g) M. Parschau, U. Ellerbeck, K.-H. Ernst, Colloids and Surfaces A: Physicochem. Eng. Aspects 2010 , 354, 240.

[18] a) M. Stöhr, S. Boz, M. Schär, M.-T. Nguyen, C. A. Pignedoli, D. Passerone, W. B. Schweizer, C. Thilgen, T. A. Jung, F. Diederich, Angew. Chem. Int. Ed. 2011, 50, 9982; b) C. M. Hauke, P. Rahe, M. Nimmrich, J. Schütte, I. G. Stará, J. Rybáček, G. Huerta-Angeles, I. Starý, M. Rohlfink, A. Kühnle, J. Phys. Chem. C 2012, 116, 4637; c) P. Rahe, M. Nimmrich, A. Greuling, J. Schütte, I. G. Stará, J. Rybáček, G. Huerta-Angeles, I. Starý, M. Rohlfink, A. Kühnle, J. Phys. Chem. C 2010, 114, 1547; d) J. Rybáček, G. Huerta-Angeles, A. Kollárovič, I. G. Stará, I. Starý, P. Rahe, M. Nimmrich, A. Kühnle, Eur. J. Org. Chem. 2011, 853.

[19] M. Parschau, R. Fasel, K.-H. Ernst, Cryst. Growth Des. 2008, 8, 1890.

[20] J. Andelman, J. Am. Chem. Soc. 1989, 111, 6536.
[21] P. E. Schipper, P. R. Harrowell, J. Am. Chem. Soc. 1983, 105, 723.

[22] J. Seibel, O. Allemann, J. S. Siegel, K.-H. Ernst, J. Am. Chem. Soc. 2013, 135, 7434

[23] L. Pasteur, Ann. Chim. Phys. 1853, 38, 437.

[24] K.A. Wheeler, R. C. Grove, R. E. Davis, W. S. Kassel, Angew. Chem. Int. Ed. 2008, 47, 78

[25] C. Roth, D. Passerone, K.-H. Ernst, Chem. Commun. 2010, 46, 8645.

[26] a) C. A. Orme, A. Noy, A. Wierzbicki, M. T. McBride, M. Grantham, H. H. Teng, P. M Dove, J. J. DeYoreo, Nature 2001, 411, 775; b) E. A. Kulp, J. A. Switzer, J. Am. Chem Soc. 2007, 122, 12584; c) N. Bouropoulos, S. Weiner, L. Addadi, Chem. Eur. J. 2001, 7, 1881; d) X. Zhao, J. Am. Chem. Soc. 2000, 122, 12584.

[27] a) J. A. Switzer, H. M. Kothari, P. Poizot, S. Nakanishi, E. W. Bohannan, Nature 2003, 425 490; b) R. Widmer, F.-J. Haug, P. Ruffieux, O. Gröning, M. Bielmann, P. Gröning, R. Fasel, $J$. Am. Chem. Soc. 2000, 128, 14103.

[28] a) M. Ortega Lorenzo, S. Haq, T. Bertrams, P. Murray, R. Raval, C. J. Baddeley, J. Phys. Chem. B 1999, 103, 10661; b) M. Parschau, B. Behzadi, S. Romer, K.-H. Ernst, Surf. Interface Anal. 2006, 38, 1607.

[29] C. Roth, D. Passerone, L. Merz, M. Parschau, K.-H. Ernst, J. Phys. Chem. C 2011, 115, 1240 ; b) C. Roth, M. Parschau, K.-H. Ernst, ChemPhysChem 2011, 12, 1572.

[30] a) M. J. Buerger, 'Elementary Crystallography: An introduction to the fundamental geometrical features of crystals', Wiley, New York, 1956.

[31] K. E. Plass, A. L. Grzesiak, A. J. Matzger, Acc. Chem. Res. 2007, 40, 287.

[32] 'Fivefold Symmetry', Ed. I. Hargittai, World Scientific, Singapore, 1992.

[33] R. Lück, Mater. Sci. Eng. A 2000, 294-296, 263.

[34] a) K. Tahara, T. Balandina, S. Furukawa, S. De Feyter, Y. Tobe, Cryst. Eng. Comm. 2011, 13, $5551 ;$ b) S.-S. Jester, E. Sigmund, S. Höger, $J$ Am. Chem. Soc. 2011, 133, 11062.
[35] G. Tomba, M. Stengel, W.-D. Schneider, A. Baldereschi, A. De Vita, ACSNano 2010, 4, 7545.

[36] D. Écija, J. I. Urgela, A. C. Papageorgiou, S. Joshi, W. Auwärter, A. P. Seitsonen, S. Klyatskaya, M. Ruben, S. Fischer, S. Vijayaraghavan, J. Reichert, J. V. Barth, Proc. Natl. Acad. Sci. USA 2013, 110, 6678.

[37] a) T. Bauert, L. Merz, D. Bandera, M. Parschau, J. S. Siegel, K.-H. Ernst, J. Am. Chem. Soc. 2009, 131, 3460; b) O. Guillermet, E. Niemi, S. Nagarajan, X. Bouju, D. Martrou, A. Gourdon, S. Gauthier, Angew. Chem., Int. Ed. 2009, 48, 1970; c) L. Zoppi, T. Bauert, J. S. Siegel, K. K. Baldridge, K.-H. Ernst, Phys. Chem. Chem. Phys. 2012, 14, 13365.

[38] M. Parschau, R. Fasel, K.-H. Ernst, O. Gröning, L. Brandenberger, R. Schillinger, T. Greber, A. P. Seitsonen, Y.-T. Wu, J. S. Siegel, Angew. Chem. Int. Ed. 2007, 46, 8258.

[39] B. Calmettes, S. Nagarajan, A. Gourdon, M. Abel, L. Porte, R. Coratger, Angew. Chem. Int. Ed. 2008, 47, 6994.

[40] a) L. Merz, M. Parschau, L. Zoppi, K. K. Baldridge, J. S. Siegel, K.-H. Ernst, Angew. Chem. Int. Ed. 2009, 48, 1966; b) L. Merz, T. Bauert, M. Parschau, G. Koller, J. S. Siegel, K.-H. Ernst, Chem. Commun. 2009, 5871.

[41] a) W. Xiao, D. Passerone, P. Ruffieux, K. AïtMansour, O. Gröning, E. Tosatti, J. S. Siegel, R. Fasel, J. Am. Chem. Soc. 2008, 130, 4767; b) T. Bauert, K. K. Baldridge, J. S. Siegel, K.-H. Ernst, Chem. Comm. 2011, 47, 7995.

[42] T. Bauert, L. Zoppi, G. Koller, A. Garcia, K K. Baldridge, K.-H. Ernst, J. Phys. Chem. Lett. 2011, 2, 2805 .

[43] a) T. Schilling, S. Pronk, B. Mulder, D. Frenkel, Phys. Rev. E 2005, 71, 036138; b) Y. Limon Duparcmeur, A. Gervois, J. P. Troadec, J. Phys.: Cond. Mat. 1995, 7, 3421; c) S. Sachdev, D. R. Nelson, Phys. Rev. B 1985, 32, 1480; d) C. L. Henley, Phys. Rev. B 1986, 34, 797.

[44] L. Merz, M. Parschau, J. S. Siegel, K.-H. Ernst, Chimia 2009, 63, 214. 